\title{
In vitro antiviral activity of plant extracts from Asteraceae medicinal plants
}

\author{
María F Visintini Jaime ${ }^{1}$, Flavia Redko ${ }^{2}$, Liliana V Muschietti ${ }^{2}$, Rodolfo H Campos ${ }^{1}$, Virginia S Martino ${ }^{2}$ \\ and Lucia V Cavallaro ${ }^{1 *}$
}

\begin{abstract}
Background: Due to the high prevalence of viral infections having no specific treatment and the constant appearance of resistant viral strains, the development of novel antiviral agents is essential. The aim of this study was to evaluate the antiviral activity against bovine viral diarrhea virus, herpes simplex virus type 1 (HSV-1), poliovirus type 2 (PV-2) and vesicular stomatitis virus of organic (OE) and aqueous extracts (AE) from: Baccharis gaudichaudiana, B. spicata, Bidens subalternans, Pluchea sagittalis, Tagetes minuta and Tessaria absinthioides. A characterization of the antiviral activity of B. gaudichaudiana OE and AE and the bioassay-guided fractionation of the former and isolation of one active compound is also reported.

Methods: The antiviral activity of the OE and AE of the selected plants was evaluated by reduction of the viral cytopathic effect. Active extracts were then assessed by plaque reduction assays. The antiviral activity of the most active extracts was characterized by evaluating their effect on the pretreatment, the virucidal activity and the effect on the adsorption or post-adsorption period of the viral cycle. The bioassay-guided fractionation of B. gaudichaudiana OE was carried out by column chromatography followed by semipreparative high performance liquid chromatography fractionation of the most active fraction and isolation of an active compound. The antiviral activity of this compound was also evaluated by plaque assay.

Results: B. gaudichaudiana and B. spicata OE were active against PV-2 and VSV. T. absinthioides OE was only active against PV-2. The corresponding three AE were active against HSV-1. B. gaudichaudiana extracts (OE and AE) were the most selective ones with selectivity index (SI) values of 10.9 (PV-2) and $>117$ (HSV-1). For this reason, both extracts of B. gaudichaudiana were selected to characterize their antiviral effects. Further bioassay-guided fractionation of $B$. gaudichaudiana OE led to an active fraction, $F_{C}\left(E C_{50}=3.1 \mu \mathrm{g} / \mathrm{ml} ; \mathrm{Sl}=37.9\right)$, which showed antiviral activity during the first $4 \mathrm{~h}$ of the viral replication cycle of PV-2 and from which the flavonoid apigenin ( $\mathrm{EC}_{50}=12.2 \pm$ $3.3 \mu \mathrm{M})$ was isolated as a major compound.
\end{abstract}

Conclusions: The results showed that, among the species studied, B. gaudichaudiana seemed to be the most promising species as a source of antiviral agents.

Keywords: Asteraceae, Antiviral activity, Baccharis gaudichaudiana, Poliovirus, Herpes simplex virus, Apigenin

\footnotetext{
* Correspondence: Icavalla@ffyb.uba.ar

${ }^{1}$ Cátedra de Virología, Facultad de Farmacia y Bioquímica, Universidad de Buenos Aires, Junín 956, 4P, Ciudad de Buenos Aires, 1113, Argentina Full list of author information is available at the end of the article
} 


\section{Background}

Antiviral drugs for diseases caused by herpesviruses, retroviruses, orthomyxoviruses, hepatitis B virus and hepatitis $\mathrm{C}$ virus (HCV) are currently commercially available [1]. However, due to the high prevalence of viral infections for which there are no specific treatment and the constant appearance of new resistant viral strains, the development of novel antiviral agents is essential.

Natural products have proved to be an important source of lead molecules and many extracts and compounds of plant origin with antiviral activity have been reported [2].

The great diversity of plants growing in Argentina offers interesting possibilities of finding novel antiviral compounds from a natural origin. Asteraceae is the most numerous and diverse plant family in our country and is highly promising from a pharmacological perspective [3].

The aim of this study was to evaluate the antiviral activity against bovine viral diarrhea virus (BVDV), herpes simplex virus type 1 (HSV-1), poliovirus type 2 (PV-2) and vesicular stomatitis virus (VSV) of organic (OE) and aqueous extracts (AE) from: Baccharis gaudichaudiana, Bac charis spicata, Bidens subalternans, Pluchea sagittalis, Tagetes minuta and Tessaria absinthioides, all medicinal plants belonging to the Asteraceae family (Table 1) in which different compounds from diverse chemical groups have been found.

The selection of the viruses was based on the clinical importance of their infections, the type of the genome and the strategies of viral replication. HSV-1, a DNA virus, is responsible of viral infections that have increased over the past decades [14] and the development of therapeutic agents has become necessary due to its growing incidence and the appearance of drug-resistant strains, especially in immunocompromised patients [15]. Poliovirus is an RNA virus that causes poliomyelitis for which there are two commercially available vaccines. Nevertheless, no complete eradication of this viral infection has been achieved [16]. There is a need to find effective drugs to complete the eradication plan and to control future outbreaks [17].

BVDV and VSV cause serious disease in livestock and are responsible for major losses in cattle. Both are RNA viruses but BVDV has a positive sense genome while VSV has a negative one. Moreover, BVDV is also accepted as a surrogate virus model for identifying and characterizing antiviral agents to be used against $\mathrm{HCV}$ [18] and VSV has been extensively studied as a prototype of non-segmented, negative-strand RNA viruses [19].

Besides the results of the antiviral screening, the preliminary characterization of the antiviral effect of the most active extracts is reported. In addition, the bioassayguided fractionation of B. gaudichaudiana organic extract, altogether with the isolation of its major antiviral compound is also described.

\section{Results}

Antiviral activity against BVDV, HSV-1, PV-2 and VSV

Six Argentinean Asteraceaes were selected for this study. Chemical, ethnopharmacological data and previously reported antiviral studies are shown in Table 1 . The antiviral activity of plant extracts against BVDV, HSV-1, PV-2 and VSV was assessed in vitro by the viral CPE reduction assay. Results obtained from this screening (Table 2) showed that B. gaudichaudiana and B. spicata OE were active against PV-2 and VSV, the AE of both species and

Table 1 Ethnopharmacological and chemical data of the medicinal plants selected

\begin{tabular}{|c|c|c|c|c|}
\hline Plant species & $\begin{array}{l}\text { Vernacular } \\
\text { Name }\end{array}$ & $\begin{array}{l}\text { Place of } \\
\text { collection }\end{array}$ & Popular use & Chemical composition \\
\hline $\begin{array}{l}\text { Baccharis } \\
\text { gaudichaudiana } \\
\text { DC }\end{array}$ & $\begin{array}{l}\text { "carqueja" } \\
\text { "chilca } \\
\text { melosa" }\end{array}$ & $\begin{array}{l}\text { Rosario, Santa } \\
\text { Fe, Argentina }\end{array}$ & $\begin{array}{l}\text { Digestive, hepatic, antidiabetic, antidiarrheal, antiseptic in } \\
\text { urinary and respiratory tract infections [4] }\end{array}$ & $\begin{array}{l}\text { Flavonoids, clerodane } \\
\text { diterpenoids, phenolics, } \\
\text { hydroxycinnamic acids [5] }\end{array}$ \\
\hline $\begin{array}{l}\text { Baccharis } \\
\text { spicata (Lam.) } \\
\text { Baill. }\end{array}$ & $\begin{array}{l}\text { "carqueja", } \\
\text { "chilca } \\
\text { blanca" }\end{array}$ & $\begin{array}{l}\text { Rosario, Santa } \\
\text { Fe, Argentina }\end{array}$ & Medicinal [6] & Diterpenoids [4] \\
\hline $\begin{array}{l}\text { Bidens } \\
\text { subalternans DC }\end{array}$ & "amor seco" & $\begin{array}{l}\text { Ciudad de } \\
\text { Buenos Aires, } \\
\text { Argentina }\end{array}$ & Ocular antiseptic, to treat aphthae and sore throat $[7,8]$ & Triterpenoids, steroids [4] \\
\hline $\begin{array}{l}\text { Pluchea } \\
\text { sagittalis (Lam.) } \\
\text { Cabrera }\end{array}$ & $\begin{array}{l}\text { "lucera" } \\
\text { "hierba } \\
\text { lucera" }\end{array}$ & $\begin{array}{l}\text { Zarate, Buenos } \\
\text { Aires, } \\
\text { Argentina }\end{array}$ & $\begin{array}{l}\text { Stomachic, hepatic, choleretic, antispasmodic, digestive, } \\
\text { cholagogue, antipyretic, antitussive, antiseptic, for } \\
\text { stomachache, febrifuge, antiseptic, for venereal diseases }[4,9]\end{array}$ & $\begin{array}{l}\text { Phenylpropanoids, flavonoids, } \\
\text { essential oils, polyphenols, } \\
\text { tannins, triterpenes [4] }\end{array}$ \\
\hline $\begin{array}{l}\text { Tagetes } \\
\text { minuta L. }\end{array}$ & "chinchilla" & $\begin{array}{l}\text { Ibicuy, Entre } \\
\text { Rios, Argentina }\end{array}$ & $\begin{array}{l}\text { Digestive, antispasmodic, diuretic, antifungal, anthelminthic, } \\
\text { antiseptic, antitussive, pectoral, disinfectant, in urinary tract } \\
\text { infections [10] }\end{array}$ & $\begin{array}{l}\text { Terpenoids, flavonoids, essential } \\
\text { oils }[11,12]\end{array}$ \\
\hline $\begin{array}{l}\text { Tessaria } \\
\text { absinthioides } \\
\text { (Hook. \& Arn.) }\end{array}$ & $\begin{array}{l}\text { "pájaro } \\
\text { bobo", } \\
\text { "suncho } \\
\text { negro" }\end{array}$ & $\begin{array}{l}\text { Trancos, } \\
\text { Tucuman, } \\
\text { Argentina }\end{array}$ & $\begin{array}{l}\text { Hypocholesterolemic, balsamic, expectorant, for hepatitis and } \\
\text { renal insufficiency [4] }\end{array}$ & $\begin{array}{l}\text { Sesquiterpenes, sulfur } \\
\text { compounds, flavonoids, essential } \\
\text { oils [13] }\end{array}$ \\
\hline
\end{tabular}


Table 2 Screening of antiviral activity of plant extracts

\begin{tabular}{llccccc}
\hline Plant name & Extracts & $\begin{array}{c}\text { Yield } \\
\text { (\%) }\end{array}$ & BVDV & HSV-1 & PV-2 & VSV \\
\hline Baccharis gaudichaudiana & OE & 29 & - & - & + & + \\
& AE & 10 & - & + & - & - \\
Baccharis spicata & OE & 15.5 & - & - & + & + \\
& AE & 9 & - & + & - & - \\
Bidens subalternans & OE & 8.4 & - & - & - & - \\
& AE & 6.3 & - & - & - & - \\
Pluchea sagittalis & OE & 11 & - & $+/-$ & - & + - \\
& AE & 11 & - & - & - & - \\
Tagetes minuta & OE & 7.5 & - & - & + - & - \\
& AE & 7.8 & - & - & - & - \\
Tessaria absinthioides & OE & 13.5 & - & - & + & - \\
& AE & 15.3 & - & + & - & - \\
\hline
\end{tabular}

The antiviral activity was tested by the reduction of viral cytopathic effect (CPE) assays.

(+) positive: reduction of viral CPE higher than $50 \%$ at both concentrations tested.

$(+/-)$ positive/negative: reduction of viral CPE only achieved at $100 \mu \mathrm{g} / \mathrm{ml}$.

(-) negative: without protection at 25 and at $100 \mu \mathrm{g} / \mathrm{ml}$

$O E$ organic extract, $A E$, aqueous extract.

Yield (\% $\mathrm{w} / \mathrm{w}=\mathrm{g}$ of extracts $/ 100 \mathrm{~g}$ of dried and ground plant material).

the AE of T. absinthioides were active against HSV-1 and $T$. absinthioides OE was active only against PV-2. None of the twelve extracts was active against BVDV.

To confirm the inhibitory effect detected in the screening, we evaluated the antiviral activity of the positive extracts by the plaque reduction assay and the SIs were determined (Table 3). Regarding the active extracts, the thin layer chromatographic (TLC) profiles of the OE of the two Baccharis species were very similar. Bands corresponding to flavonoid aglycones and terpenoids were observed after spraying with NPR and anisaldehyde/ $\mathrm{H}_{2} \mathrm{SO}_{4}$.
On the other hand, Tessaria absinthioides OE showed strong bands corresponding to flavonoid glycosides and only weak bands corresponding to terpenoids in the $\mathrm{OE}$ and $\mathrm{AE}$ (Additional file 1).

B. gaudichaudiana $\mathrm{OE}$ and $\mathrm{AE}$ exhibited the highest SI values against PV-2 (10.9) and HSV-1 (>117), respectively. Based on these results, both extracts were selected to characterize the antiviral activity.

\section{Characterization of antiviral activity}

In order to characterize the antiviral activity against PV2 and HSV-1, different experimental approaches were considered for the $\mathrm{OE}$ and $\mathrm{AE}$ of $B$. gaudichaudiana.

In the pretreatment assay, none of the extracts protected Vero cells against PV-2 or HSV-1 infection after $7 \mathrm{~h}$ of incubation at the evaluated concentrations (Figure 1).

When the virucidal activity was assessed, the OE did not prove to have this effect against PV-2 since 10 and $20 \%$ of reduction of viral infectivity was obtained at r.t. and $37^{\circ} \mathrm{C}$, respectively. In contrast, higher values were obtained for the AE against HSV-1 with values of $85 \%$ and $97 \%$, at r.t. and $37^{\circ} \mathrm{C}$, respectively (Figure 1 ).

With the aim to determine whether the inhibitory effect of the extracts occurs during the adsorption or postadsorption steps of the viral cycle, different experimental conditions were evaluated with $1 \mathrm{xEC}_{90}$ of $\mathrm{OE}$ and $\mathrm{AE}$ (Figure 2A). The results obtained demonstrated that $B$. gaudichaudiana $\mathrm{OE}(30 \mu \mathrm{g} / \mathrm{ml})$ reduced the formation of PV-2 plaques when it was added after the adsorption period. This reduction in the number of plaques was similar to that obtained when the OE was present during all the experimental time (Throughout) (Figure 2B).

In contrast, B. gaudichaudiana $\mathrm{AE}(35 \mu \mathrm{g} / \mathrm{ml})$ interfered in the adsorption step of HSV-1 to Vero cells and caused an inhibition degree similar to that obtained

Table 3 Antiviral activity of selected active extracts

\begin{tabular}{|c|c|c|c|c|c|c|}
\hline Plant name & Extract & Virus & $\mathrm{CC}_{50}{ }^{\mathrm{a}}(\mu \mathrm{g} / \mathrm{ml})$ & $\mathrm{EC}_{90}^{\mathrm{b}}(\mu \mathrm{g} / \mathrm{ml})$ & $\mathrm{EC}_{50}{ }^{\mathrm{c}}(\mu \mathrm{g} / \mathrm{ml})$ & $\mathrm{SI}^{\mathrm{d}}$ \\
\hline \multirow[t]{3}{*}{ Baccharis gaudichaudiana } & $\mathrm{OE}$ & PV-2 & $161.0 \pm 2.5$ & $30.1 \pm 0.8$ & $14.8 \pm 1.5$ & 10.9 \\
\hline & & VSV & & $114.0 \pm 0.5$ & $33.9 \pm 3.8$ & 4.8 \\
\hline & $\mathrm{AE}$ & HSV-1 & $>2000$ & $35.4 \pm 1.2$ & $17.1 \pm 0.1$ & $>117$ \\
\hline \multirow[t]{3}{*}{ Baccharis spicata } & $\mathrm{OE}$ & PV-2 & $114.3 \pm 4.7$ & $74 \pm 4.7$ & $19.3 \pm 3.9$ & 5.9 \\
\hline & & VSV & & $110.1 \pm 1.6$ & $23.8 \pm 0.1$ & 4.8 \\
\hline & $\mathrm{AE}$ & HSV-1 & $>2000$ & $61.3 \pm 3.2$ & $34.7 \pm 3.2$ & $>57.6$ \\
\hline \multirow[t]{2}{*}{ Tessaria absinthioides } & $\mathrm{OE}$ & PV-2 & $390.1 \pm 3.2$ & $61.1 \pm 2.8$ & $40.3 \pm 5.6$ & 9.7 \\
\hline & $\mathrm{AE}$ & HSV-1 & $>2000$ & $26.5 \pm 1.5$ & $19.1 \pm 3.2$ & $>104$ \\
\hline Acyclovir* & & HSV-1 & $>9^{\#}$ & & $1.9 \pm 0.2^{\S}$ & $>90000$ \\
\hline Guanidine* & & PV-2 & $>84^{\#}$ & & $0.2 \pm 0.6^{\#}$ & $>420$ \\
\hline Ribavirin* & & VSV & $>2^{\#}$ & & $0.3 \pm 1.2^{\#}$ & $>6.7$ \\
\hline
\end{tabular}

${ }^{a} C C_{50}$ cytotoxic concentration $50,{ }^{b} E C_{90}$ effective concentration $90,{ }^{C} E C_{50}$ effective concentration $50,{ }^{d} S /$ (Selectivity index) $=C C_{50} / E C_{50}, O E$ organic extract, $A E$ aqueous extract. Results are shown as means \pm SD, each time in triplicate.

*Acyclovir, Guanidine and Ribavirin were included as positive controls for the antiviral activity of HSV-1 and PV-2 and VSV, respectively. The $C C_{50}$ and $E C_{50}$ values were expressed in $\mathrm{mM}\left({ }^{*}\right)$, except for $\mathrm{EC}_{50}$ of acyclovir that is expressed in $\mu \mathrm{M}\left({ }^{\S}\right)$. 


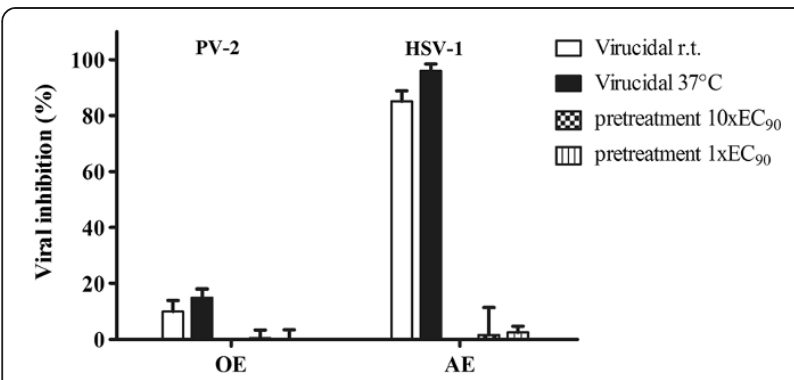

Figure 1 Virucidal activity and the effect of pretreatment with $B$. gaudichaudiana $\mathrm{OE}$ and $\mathrm{AE}$. The virucidal activity and the pretreatment of 10xEC $(\mathrm{OE}=300 \mu \mathrm{g} / \mathrm{ml} \mathrm{AE}=350 \mu \mathrm{g} / \mathrm{ml})$ and $1 \times C_{90}(\mathrm{OE}=30 \mu \mathrm{g} / \mathrm{ml}, \mathrm{AE}=35 \mu \mathrm{g} / \mathrm{ml})$ were evaluated against PV-2 and HSV-1, respectively. Data represent \% of virus inhibition compared to untreated controls as mean $\pm \operatorname{SD}(n=3)$, each time in quadruplicate.

when it was present throughout the experimental time. The reduction of $25 \%$ observed in the post-adsorption condition could be due to the inhibitory effect of this extract on the adsorption steps on the subsequent HSV-1 replication cycles occurring during the $48 \mathrm{~h}$ incubation period carried out at $37^{\circ} \mathrm{C}$ (Figure 2B).

\section{Bioassay-guided fractionation of $B$. gaudichaudiana $\mathrm{OE}$}

B. gaudichaudiana $\mathrm{OE}$ was fractionated by a silicagel column chromatography. Eight final fractions were obtained according with their TLC profiles. The results obtained in the evaluation of the anti-PV-2 activity demonstrated that $\mathrm{F}_{\mathrm{C}}$ was the most active fraction with a $\mathrm{SI}=56.4$ and $\mathrm{EC}_{50}=2.1 \pm 0.1 \mu \mathrm{g} / \mathrm{ml}$ followed by $\mathrm{F}_{\mathrm{D}}$ $\mathrm{SI}=44.1$ and $\mathrm{EC}_{50}=2.5 \pm 0.3 \mu \mathrm{g} / \mathrm{ml}$ (Table 4). The HPLC profile obtained for $F_{D}$ was similar to that of $F_{C}$ but based on the SI value and the yield, $\mathrm{F}_{\mathrm{C}}$ was selected for further characterization (Additional file 2).

To define the post-adsorption steps of the viral cycle that could be targeted by $\mathrm{F}_{\mathrm{C}}$, the effect of the addition of
$\mathrm{F}_{\mathrm{C}}\left(10 \mathrm{xEC} \mathrm{C}_{90}=22 \mu \mathrm{g} / \mathrm{ml}\right)$ at different times of infection on PV-2 production at $10 \mathrm{~h}$ p.i. was evaluated (Figure 3). The results obtained demonstrated that the maximum inhibition level was exerted when $\mathrm{F}_{\mathrm{C}}$ was present before $4 \mathrm{~h}$ of infection.

A semipreparative HPLC of $\mathrm{F}_{\mathrm{C}}$ was then performed and four subfractions $\left(\mathrm{F}_{\mathrm{C} 1}-\mathrm{F}_{\mathrm{C} 4}\right)$ were collected. The antiviral activity against PV-2 was detected in $\mathrm{F}_{\mathrm{C} 2}\left(\mathrm{EC}_{50}=3.3 \pm 0.3\right.$ $\mu \mathrm{g} / \mathrm{ml})$ and $F_{C 3}\left(E_{50}=1.8 \pm 0.1 \mu \mathrm{g} / \mathrm{ml}\right.$ ) (Figure 4). The $\mathrm{CC}_{50}$ value of $\mathrm{F}_{\mathrm{C} 3}$ was higher than $100 \mu \mathrm{g} / \mathrm{ml}$ and the $\mathrm{SI}$ was > 55.6. A major pure compound was isolated from $\mathrm{F}_{\mathrm{C} 3}$ by semipreparative HPLC (Figure 5) and identified as apigenin (Figure 6) by comparison of its spectral data (Additional file 3 and Additional file 4) with literature values [20] and by HPLC comparison with a reference standard (Additional file 5). The antiviral activity of apigenin was determined by plaque assay with $\mathrm{EC}_{50}=12.2 \pm$ $3.3 \mu \mathrm{M}$. Its $\mathrm{CC}_{50}$ value was $230.7 \pm 4.4 \mu \mathrm{M}$; in consequence the SI was 18.9. The apigenin standard exhibited similar values of $\mathrm{EC}_{50}$ and $\mathrm{CC}_{50}$ (data not shown).

\section{Discussion}

Several Baccharis species have been reported to have antiviral activity: B. genistelloides [21], B. teindalensis [22], B. trinervis [23], B. coridifolia [24] and B. articulata [25] but this is the first report on the antiviral activity of $B$. gaudichaudiana and B. spicata. Although the virucidal activity of T. absinthioides essential oil was reported previously against HSV-1 and Junín virus [13], this is the first report of the antiviral activity of the $\mathrm{OE}$ and $\mathrm{AE}$ obtained from this plant.

In the characterization of the antiviral activity of $B$. gaudichaudiana AE, this extract did not affect HSV-1 replication when it was added to the cell culture before infection, thus, it is unlikely that its antiviral activity could be due to direct effects on the host's cell. On the
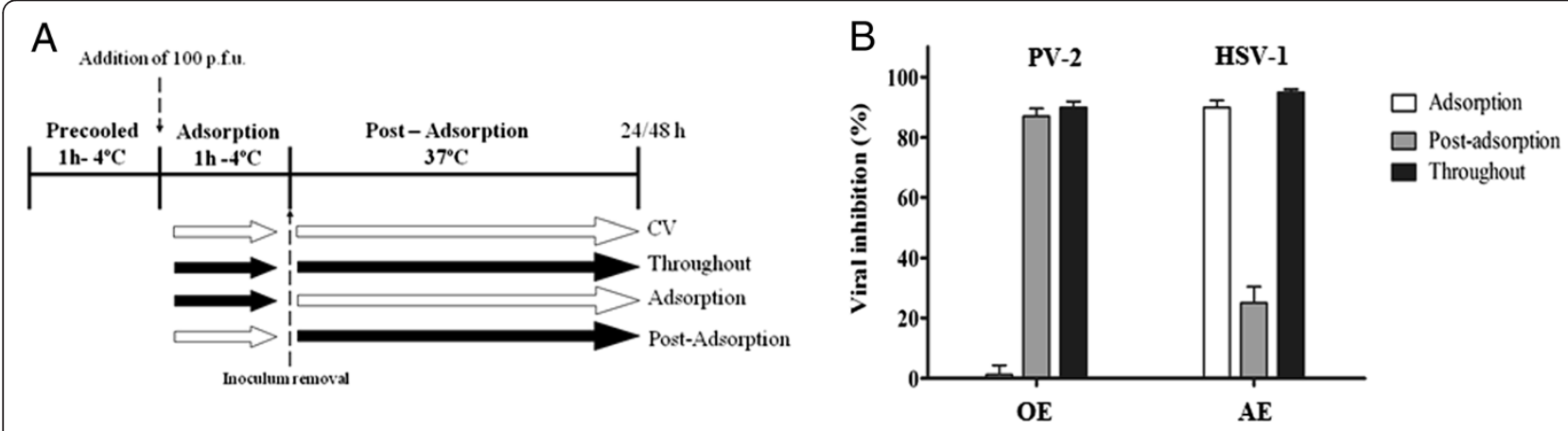

Figure 2 Effect of B. gaudichaudiana OE and AE in the adsorption and post-adsorption steps of PV-2. A. Scheme of addition of OE or AE. Open and black arrows indicate the absence and presence of extract, respectively. B.- Percentage of viral inhibition under different experimental conditions. $1 \times \mathrm{EC}_{90}$ was used for the experiments. Data represented $\%$ of virus inhibition compared to untreated control as mean $\pm \operatorname{SD}(n=3)$, each time by quadruplicate. 
Table 4 Antiviral activity of fractions of B. gaudichaudiana OE

\begin{tabular}{lcccc}
\hline Fraction & Yield (\%) & $\mathbf{C C}_{\mathbf{5 0}}{ }^{\mathbf{a}}(\boldsymbol{\mu} \mathbf{g} / \mathbf{m l})$ & $\mathrm{EC}_{\mathbf{5 0}}{ }^{\mathbf{b}}(\boldsymbol{\mu} \mathbf{g} / \mathbf{m l})$ & $\mathbf{S l}^{\mathbf{c}}$ \\
\hline$F_{A}$ & 1.43 & $396.7 \pm 14.4$ & $15.4 \pm 1.0$ & 25.8 \\
$F_{B}$ & 1.35 & $196.1 \pm 6.1$ & $7.6 \pm 0.4$ & 25.8 \\
$F_{C}$ & 2.56 & $118.5 \pm 6.5$ & $2.1 \pm 0.1$ & 56.4 \\
$F_{D}$ & 0.66 & $110.2 \pm 7.9$ & $2.5 \pm 0.3$ & 44.1 \\
$F_{E}$ & 2.14 & $390.9 \pm 10.9$ & $38.4 \pm 3.8$ & 10.2 \\
$F_{F}$ & 1.68 & $390.4 \pm 10.4$ & $33.1 \pm 4.8$ & 11.8 \\
$F_{G}$ & 0.75 & $412.3 \pm 7.1$ & $27.4 \pm 3.9$ & 15.0 \\
$F_{H}$ & 0.31 & $729 \pm 3.1$ & $20.8 \pm 3.6$ & 35.1 \\
\hline
\end{tabular}

${ }^{a} C C_{50}$ cytotoxic concentration $50,{ }^{b} E C_{50}$ effective concentration $50,{ }^{c} \mathrm{Sl}$ (Selectivity index) $=C C_{50} / E C_{50}$ Yield (\% w/w $=\mathrm{g}$ of fraction $/ 100 \mathrm{~g}$ of OE). Results are shown as mean $\pm S D(n=3)$, each time in quadruplicate.

other hand, the results of the virucidal assays suggest that this extract could interact with viral particles and inactivate them. Data also indicated that HSV-1 infection was significant impaired only if the $\mathrm{AE}$ was present at the time of adsorption. Therefore, these results suggest that $\mathrm{AE}$ may exert its antiviral activity by inactivation of viral particles at high concentrations and possibly by interference of the adsorption step of the virus to the cells at non-virucidal concentrations.

Upon characterizing the antiviral activity of B. gaudi chaudiana OE against PV-2, it could be considered that this extract had a true antiviral activity against this virus because of its ability to inhibit the viral cycle, particularly during the post-adsorption period. In the present study, B. gaudichaudiana $\mathrm{OE}$ was selected for further purification and isolation of antiviral principles by bioassay-guided fractionation. The most active fraction obtained, $F_{C}$, exerted the maximum inhibition of PV-2 replication when it was present before $4 \mathrm{~h}$ p.i. At this time of the poliovirus replication cycle, the synthesis of viral RNA is maximum [26,27]. Taking into account the results obtained, it can be deduced that $\mathrm{F}_{\mathrm{C}}$ might exert its antiviral activity at an intermediate stage of virus life cycle and could interfere with viral RNA synthesis and polyprotein processing/synthesis.

From this active fraction the flavonoid apigenin (5, 7dihydroxy-2-(4-hydroxylphenyl)-4H -chromen-4-one) was isolated. This compound has previously been reported from B. gaudichaudiana [28]. It has been demonstrated that apigenin is active against different viruses, including avian influenza $\mathrm{H} 5 \mathrm{~N} 1$ virus strain, hepatitis $\mathrm{C}$ virus, HSV and human immunodeficiency virus [29-32].

Although apigenin exhibited antiviral activity against PV-2 $\left(\mathrm{EC}_{50}=12.2 \pm 3.3 \mu \mathrm{M}\right)$, HPLC profile of $\mathrm{F}_{\mathrm{C} 3}$ showed the presence of other minor compounds which could be responsible, altogether with apigenin, of the antiviral activity observed.

Further studies are under way to characterize the mechanism of action of apigenin against PV-2.

To our knowledge, this is the first time that the antiviral activity of B. gaudichaudiana is reported and the anti-poliovirus activity of apigenin is determined.

\section{Conclusion}

In this study we have shown that the organic extract of B. gaudichaudiana shows high antiviral effect against PV-2 and the isolated compound, apigenin could be, at least in part, responsible for the antiviral activity

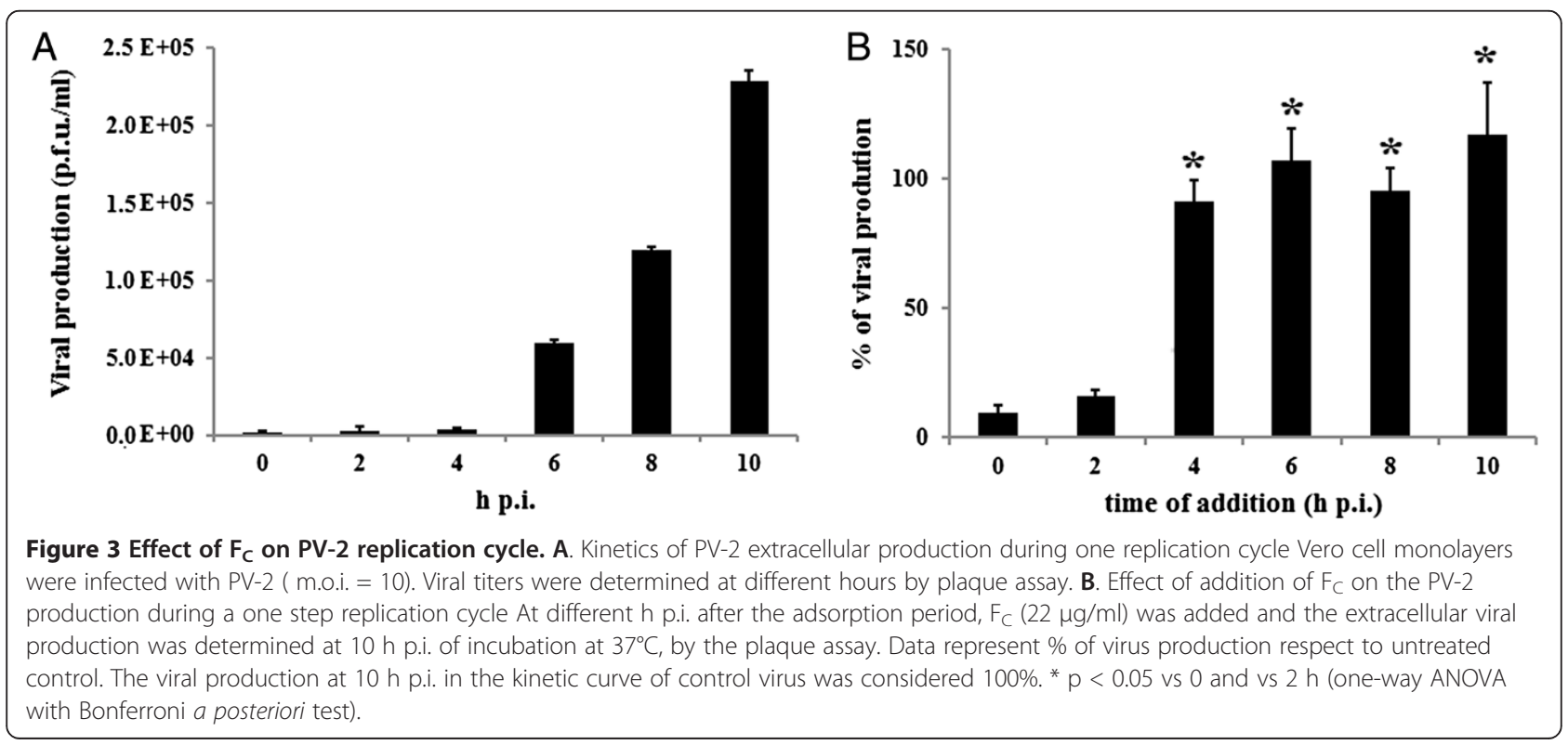




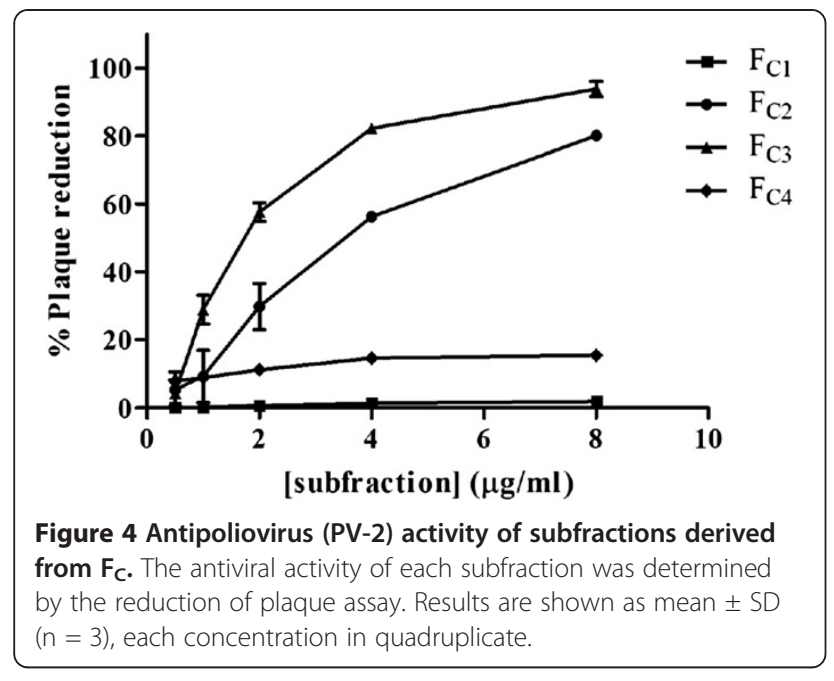

observed. Further studies are necessary for a better understanding of the mechanism of action of apigenin.

Moreover, since the aqueous extract of B. gaudichau diana was active against HSV-1, the bioassay guided fractionation of this extract will be carried out.

\section{Methods}

\section{Plant material}

Plant samples (aerial parts with flowers) were collected between 2008 and 2010 in their places of origin in Argentina. Voucher specimens are deposited as follows: B. gaudichaudiana (1655): Botany Herbarium at Facultad de Ciencias Bioquímicas y Farmacéuticas, Universidad Nacional de Rosario, Argentina; B. spicata (BAF 711), Bidens subalternans (BAF 704), Pluchea sagittalis (BAF 709) and Tagetes minuta (BAF 714): Herbarium at Museo de Farmacobotánica, Facultad de Farmacia y Bioquímica, Universidad de Buenos Aires; Tessaria absinthioides (Slanis-Juarez 1041): Herbarium of Fundación Miguel A. Lillo, Universidad de Tucumán. Botanical and vernacular names, popular uses and reported chemical composition are shown in Table 1.

\section{Extraction of plant material}

Dried aerial parts of each plant $(10 \mathrm{~g})$ were reduced to powder and extracted by soaking in $100 \mathrm{ml}$ of dichloromethane: methanol (1:1) at room temperature (r.t.) for $24 \mathrm{~h}$ and then vacuum-filtered. The process was repeated twice and the filtrates were combined and dried under vacuum to obtain the organic extract $(\mathrm{OE})$. The marc of the plant material was further extracted with distilled water under the same conditions. The aqueous extracts (AE) were lyophilized. For the antiviral assays, $\mathrm{OE}$ and $\mathrm{AE}$ were dissolved in dimethylsulfoxide and sterile distilled water, respectively.

\section{Cells and virus strains}

Vero cells (ATCC CCL 81) were obtained from Asociación Banco Argentino de Células and cultured in growth medium consisting of Eagle's Minimal Essential Medium (E-MEM) supplemented with $10 \%$ fetal bovine serum (FBS) (PAA), $100 \mu \mathrm{g} / \mathrm{ml}$ streptomycin, $100 \mathrm{IU} / \mathrm{ml}$ penicillin, $2 \mathrm{mM}$ L-glutamine, $2.25 \mathrm{~g} / \mathrm{L}$ sodium bicarbonate and non-essential amino acids $(100 \mu \mathrm{M})\left(\right.$ Gibco), at $37^{\circ} \mathrm{C}$ in a $5 \% \mathrm{CO}_{2}$ incubator. The infection medium (IM), used for the antiviral assays, was the same as the growth medium but $2 \%$ FBS was added instead. The plaque medium (PM) was IM supplemented with $1 \%$ methylcellulose (Sigma). Madin-Darby Bovine Kidney cells (MDBK) (ATCC CLL 22) were grown in growth medium supplemented with

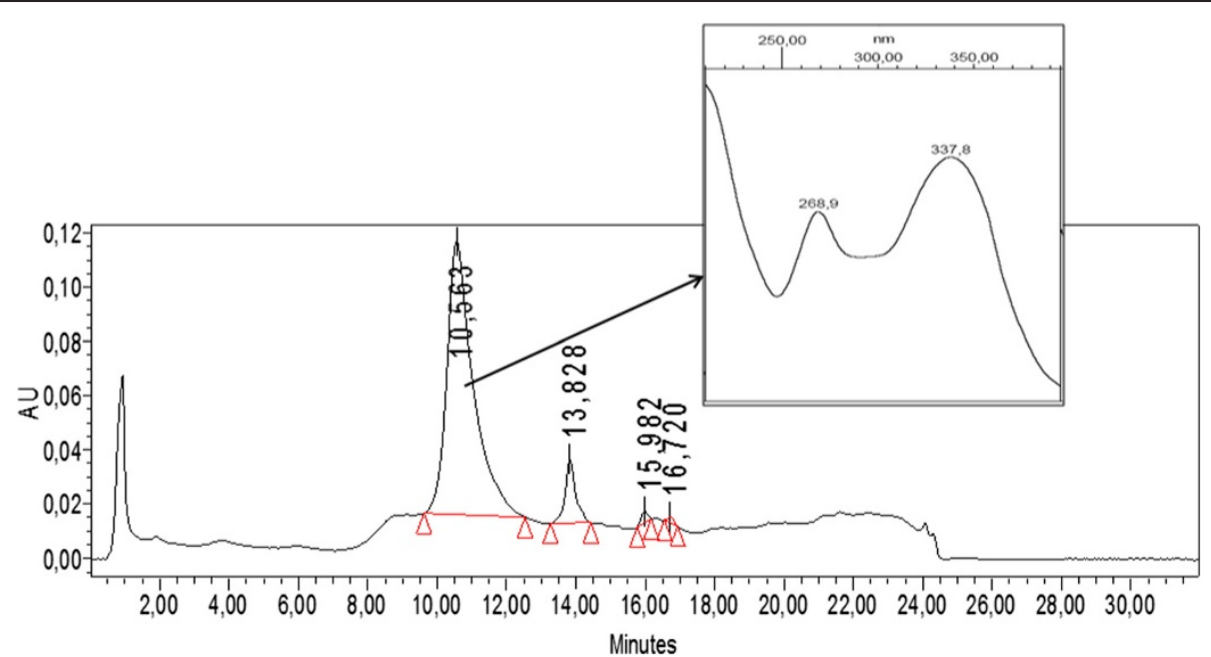

Figure 5 HPLC profile of $\mathbf{F}_{\mathbf{C} 3}$. HPLC: RP-18 column, using a water (A)-methanol (B) gradient: 0-2 50\% A; 2-15 min: $50 \rightarrow 98 \%$ A, 15-25 min: isocratic 98\% A, 26-30 min: $98 \rightarrow 50 \%$ A, flow rate $=1 \mathrm{ml} / \mathrm{min}$, monitored at $336 \mathrm{~nm}$. The insert shows the UV adsorption spectra of the major peak detected. 


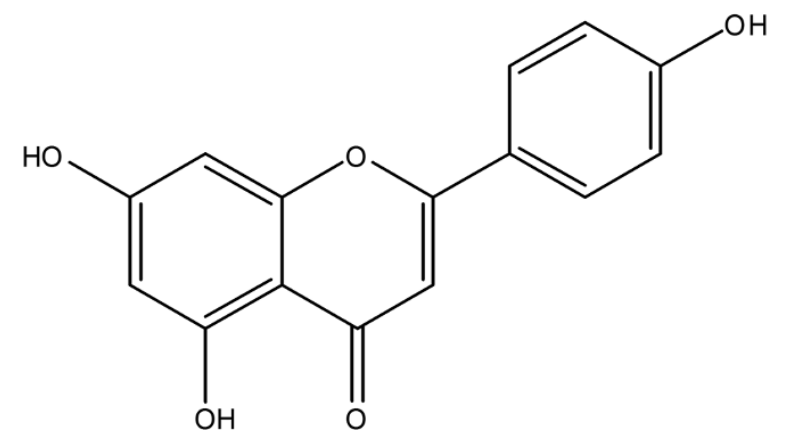

Figure 6 Chemical structure of apigenin: 5, 7-dihydroxy-2-

(4-hydroxylphenyl)-4H -chromen-4-one, $\mathrm{C}_{15} \mathrm{H}_{10} \mathrm{O}_{5}$, MW: 270.24 .

$10 \%$ of $\gamma$-irradiated FBS. IM for the MDBK cell line was supplemented with $2.5 \%$ horse serum (Gibco).

The herpes simplex type 1 (HSV-1) F strain, the poliovirus type 2 (PV-2) Sabin strain and the bovine viral diarrhea virus (BVDV:NADL strain cytopathic biotype were kindly provided by Dr. Albert Epstein, Dr. María Cecilia Freire (ANLIS-Instituto Dr. Carlos G. Malbrán, Argentina) and Dr. Laura Weber (INTA, Castelar, Argentina), respectively. VSV, Indiana strain (ATCC VR1421), was purchased from ATCC. Virus stocks of HSV$1, \mathrm{PV}-2$ and VSV were propagated and quantified in Vero cells. BVDV was propagated and quantified in MDBK cells. Virus quantification was performed by plaque assay method as number of plaque forming units per $\mathrm{ml}$ (p.f.u. $/ \mathrm{ml}$ ). All virus stocks were stored at $-70^{\circ} \mathrm{C}$ until used.

\section{Screening of antiviral activity}

The antiviral activity of each plant extract was screened in 96-well culture plates by measuring the reduction of the viral cytopathic effect (CPE). Confluent Vero and subconfluent MDBK cell monolayers were infected with HSV-1, PV-2 or VSV or with BVDV, respectively, at a multiplicity of infection (m.o.i.) of 0.01 p.f.u./cell in the presence of 25 and $100 \mu \mathrm{g} / \mathrm{ml}$ of each OE/AE. Infected cells in the absence of extract as control virus and mock-infected cells with and without extract as control cells and cytotoxicity control were included. Plates were incubated at $37^{\circ} \mathrm{C}$ in a humidified atmosphere containing $5 \% \mathrm{CO}_{2}$ until $90 \%$ of viral $\mathrm{CPE}$ in the $\mathrm{CV}$ was reached. The reduction of viral CPE was determined by measuring cell viability by the tetrazolium salt/phenazine methosulfate (MTS/PMS) colorimetric assay (CellTiter $96^{\mathrm{ma}}$ Promega, Madison, WI, USA). The absorbance at $490 \mathrm{~nm}$ was measured in a Multi-Mode microplate reader (Synergy ${ }^{\mathrm{Tm}}$ HT, BioTek). Results of the screening were expressed as positive $(+)$ (reduction in the CPE at both concentrations tested), negative $(-)$ (absence of reduction in the CPE) and (+/-) (reduction in CPE only at $100 \mu \mathrm{g} / \mathrm{ml}$ ).

\section{Cytotoxicity assay: determination of cytotoxic concentration $50\left(\mathrm{CC}_{50}\right)$}

The cytotoxic effect of B. gaudichaudiana, B. spicata and $T$. absinthioides $\mathrm{OE}$ and $\mathrm{AE}$ on Vero cells was determined by the MTS/PMS method, as previously described [33]. Briefly, subconfluent monolayers of Vero cells $\left(8 \times 10^{3}\right.$ cells/well; 24 h culture) were incubated in quadruplicate in 96-multiwell plates in the presence of two-fold dilutions of the extracts for $72 \mathrm{~h}$ at $37^{\circ} \mathrm{C}$. Cell viability (\%) was calculated for each concentration as Abs treated $/ A b s_{C C} \times 100$, where $\mathrm{Abs}_{\text {treated }}$ and Abs ${ }_{C C}$ are the absorbance readings for the wells with and without extract, respectively. The $\mathrm{CC}_{50}$ is defined as the concentration that reduced cell viability by $50 \%$ with respect to controls without drug. The $\mathrm{CC}_{50}$ value was derived from the corresponding dose-response curves. The maximum non-cytotoxic concentration (MNCC) is defined as the maximum concentration of the extract that leaves $100 \%$ of viable cells.

\section{Antiviral assay: determination of effective concentration $50\left(\mathrm{EC}_{50}\right)$}

The effective concentration $50\left(\mathrm{EC}_{50}\right)$ is the concentration of extract that reduces the number of viral plaques by $50 \%$ with respect to control virus (without extract). This parameter was determined by the plaque reduction assay. Briefly, monolayers of Vero cells grown in a 24-well plate $\left(24 \mathrm{~h} ; 5 \% \mathrm{CO}_{2} ; 37^{\circ} \mathrm{C}\right)$ were infected with 100 p.f.u./well of PV-2, VSV or HSV-1 in either the absence or presence of serial two-fold dilutions from the MNCC of B. gaudichaudiana, B. spicata and $T$. absinthioides extracts (treated). After $45 \mathrm{~min}$ incubation at $37^{\circ} \mathrm{C}$, the viral inoculum was removed, and the cell monolayers were washed with phosphate buffer saline (PBS) and overlaid with PM supplemented with the corresponding concentrations of each extract. PM without extract was added in $\mathrm{CC}$ and $\mathrm{CV}$ wells. After $24 \mathrm{~h}$ at $37^{\circ} \mathrm{C}$ for PV-2 and VSV or $48 \mathrm{~h}$ for HSV-1, cell monolayers were fixed and stained with $0.75 \%$ crystal violet in methanol:water (40:60) and viral plaques were counted. Reduction of plaques (\%) was calculated as: $\left[1-\left(\mathrm{n}^{\circ}\right.\right.$ plaques treated $/ \mathrm{n}^{\circ}$ plaques $\left.\left.\mathrm{CV}\right)\right] \times 100$. The $\mathrm{EC}_{50}$ values were calculated by regression analysis of the doseresponse curves generated with the data.

The selectivity index (SI) was calculated as the $\mathrm{CC}_{50} /$ $\mathrm{EC}_{50}$ ratio.

Acyclovir (Filaxis); Guanidine.HCl (Sigma-Aldrich, St. Louis, MO) and Ribavirin (MP Biomedicals, LLC) were tested simultaneously as positive controls for HSV-1, PV-2 and VSV, respectively.

\section{Chromatographic profile- thin layer chromatography}

Chromatographic analysis of positive OE were performed by thin layer chromatography (TLC) on silica gel layers 
(Silica gel $60 \mathrm{~F}_{254}$ EMD Chemicals Inc.) using a- ethyl acetate:toluene:formic acid:methanol (2:2:1:1) and Natural Product Reagent (NPR- 2-aminoethildiphenilboric acid Sigma) as visualization reagents; and b- toluene:ethylacetate (5:5) and sulphuric/anisaldehyde (SAni) as reagent. The positive $\mathrm{AE}$ were tested on: a) silica gel layers using ethylacetate:methanol:water (50:6:5) and SAni reagent; and b) Cellulose plate (Polygram ${ }^{\circ} \mathrm{CEL} 300 \mathrm{UV}_{254}$ - Macherey Nagel) using acetic acid $15 \%$ and NPR as reagent. In all cases, the TLC plates were visualized under UV light (254 and $366 \mathrm{~nm}$ ) and visible light.

\section{Characterization of the antiviral activity Virucidal activity}

The virucidal activity was measured by in vitro incubation of viruses with the extracts. Briefly, $10^{6}$ p.f.u. of PV2 or $\mathrm{HSV}-1$ were incubated for $30 \mathrm{~min}$ at r.t. or at $37^{\circ} \mathrm{C}$ with $10 \mathrm{xEC}_{90}$ of $B$. gaudichaudiana $\mathrm{OE}(300 \mu \mathrm{g} / \mathrm{ml})$ or AE $(350 \mu \mathrm{g} / \mathrm{ml})$, respectively. Simultaneously, the same amount of virus was incubated with IM without extract as control. The residual infectious viruses were quantified by viral plaque assays.

\section{Pretreatment assays}

To assess the effect of the pretreatment with $B$. gaudichaudiana extracts, Vero cell monolayers seeded in 24-well plates were treated for $7 \mathrm{~h}$ at $37^{\circ} \mathrm{C}$ with two concentrations of the extract $10 \mathrm{xEC}_{90}$ and $1 \mathrm{xEC}_{90}(\mathrm{OE}$ : 300 and $30 \mu \mathrm{g} / \mathrm{ml}$ and AE: 350 and $35 \mu \mathrm{g} / \mathrm{ml}$, respectively). Then, the medium was removed and washed with PBS, and the cell monolayers were infected with 100 p.f. $\mathrm{u}$. of PV-2 or HSV-1/well in the absence of the extracts. Mock-infected cells (CC) and cells pretreated with IM (CV) were included in each assay. After $45 \mathrm{~min}$ at $37^{\circ} \mathrm{C}$, the viral inoculum was removed and PM without extract was added and further incubated at $37^{\circ} \mathrm{C}$ for 24 or $48 \mathrm{~h}$. Finally, the number of viral plaques was determined.

\section{Time-of-addition assay}

To study the effect of the extracts in the adsorption and post-adsorption events, three different treatments with B. gaudichaudiana $\mathrm{OE}\left(1 \mathrm{xEC} \mathrm{C}_{90}=30 \mu \mathrm{g} / \mathrm{ml}\right)$ against PV2 or $\mathrm{AE}\left(1 \mathrm{xEC}_{90}=35 \mu \mathrm{g} / \mathrm{ml}\right)$ against HSV-1 were carried out. B. gaudichaudiana $\mathrm{OE}$ and $\mathrm{AE}$ were present: (i) only during the adsorption period (Adsorption); (ii) after adsorption and until the end of the experiment (PostAdsorption), and (iii) during and after the adsorption (Throughout). Briefly, Vero cell monolayers cultured in 24-well plates were precooled for $1 \mathrm{~h}$ at $4^{\circ} \mathrm{C}$. Cells were then infected with 100 p.f.u. of virus/well in the presence or absence of $\mathrm{OE} / \mathrm{AE}$ and further incubated at $4^{\circ} \mathrm{C}$ for 1 $\mathrm{h}$ allowing only the adsorption step of the viral particles to the cells (Adsorption). Cell monolayers were washed with PBS, and then PM with or without extract was added. The number of viral plaques was determined after $24 \mathrm{~h}$ and $48 \mathrm{~h}$ for PV-2 and HSV-1, respectively.

\section{Bioassay-guided fractionation of Baccharis gaudichaudiana OE}

B. gaudichaudiana aerial parts (500 g) were air-dried, ground to powder and extracted with dichloromethane: methanol (1:1) and the extract was taken to dryness. Thirty grams of this OE was fractionated by silica gel 60 (500 g) column chromatography eluted with a step gradient of hexane:ethylacetate (100:0 to 0:100) and ethylacetate: methanol (100:0 to 0:100) to afford 21 fractions of $500 \mathrm{ml}$ each. Eluates were monitored by thin-layer chromatography (TLC) on silica gel $60 \mathrm{~F}_{254}$ using toluene-ethyl acetate (1:1) and cellulose layers using acetic acid $40 \%$ and combined into eight final fractions $\left(\mathrm{F}_{\mathrm{A}}\right.$ to $\left.\mathrm{F}_{\mathrm{H}}\right)$ according to their TLC profiles.

Fraction $\mathrm{F}_{\mathrm{C}}$ was further fractionated by a semipreparative reverse-phase HPLC (Waters 2996 - Photodiode Array Detector-Waters 600 pump) on a RP-18 column (LiChrospher 100, $5 \mu \mathrm{m}$, LiChroCART $125 \times 4-$ Merck). The injection volume was $50 \mu$ l. Elution was performed at a flow rate of $1 \mathrm{ml} /$ min. The mobile phase used consisted of water (A) and methanol (B): 0-15 min: isocratic 50\% A, 15-25 min: $50 \rightarrow$ $98 \%$ A, 25-30 min: isocratic 98\% A, 30-31 min: $98 \rightarrow 50 \%$ A. Eluates were monitored at $254 \mathrm{~nm}$. Eluates were collected into four subfractions: $\mathrm{F}_{\mathrm{C} 1}$ (0-13 min), $\mathrm{F}_{\mathrm{C} 2}$ (13-20 min), $\mathrm{F}_{\mathrm{C} 3}$ (20-25 $\mathrm{min})$ and $\mathrm{F}_{\mathrm{C4}}(25-30 \mathrm{~min})$.

The $\mathrm{F}_{\mathrm{C} 3}$ subfraction was subjected to reverse-phase HPLC on RP-18 column (LiChrospher ${ }^{\odot} 100,5 \mu \mathrm{m}$, LiChroCART $125 \times 4-$ Merck), using a water (A)-methanol (B) gradient: 0-2 50\% A; 2-15 min: $50 \rightarrow 98 \%$ A, 15-25 min: isocratic $98 \% \mathrm{~A}, 26-30 \mathrm{~min}: 98 \rightarrow 50 \% \mathrm{~A}$ and a flow rate $=1 \mathrm{ml} / \mathrm{min}$ and a pure compound was isolated. Eluates were monitored at $336 \mathrm{~nm}$.

The anti-PV-2 activity of fractions $\mathrm{F}_{\mathrm{A}}-\mathrm{F}_{\mathrm{H}}$ and subfractions $\mathrm{F}_{\mathrm{C} 1}-\mathrm{F}_{\mathrm{C} 4}$ and the pure compound was determined by viral plaque reduction assay at concentrations ranging from 100 to $0.1 \mu \mathrm{g} / \mathrm{ml}$ in Vero cells. The cytotoxicity and SI were also evaluated as previously described.

\section{Identification of apigenin}

The pure compound obtained from $\mathrm{F}_{\mathrm{C} 3}$ was identified by ultraviolet spectroscopy (UV) (Jasco V-630), infrared spectroscopy (IR) (Nicolet 380 FT-IR-Smart Multi Bruce HATR, Zn Se $45^{\circ}$ ) and HPLC/DAD by comparison with authentic sample (Sigma-Aldrich, St. Louis, MO) and comparison with literature data.

\section{One-step replication curve: effect of fraction $\mathrm{F}_{\mathrm{C}}$ on PV-2 replication}

Confluent Vero cell monolayers cultured in a 96-well plate were infected with PV-2 (m.o.i. $=10)$ for $1 \mathrm{~h}$ at $4^{\circ} \mathrm{C}$. Following the adsorption period, cells were washed three times, and 
$\mathrm{F}_{\mathrm{C}}\left(22 \mu \mathrm{g} / \mathrm{ml}=10 \times \mathrm{xEC}_{50}\right)$ was added at different hours postinfection (p.i): 0, 2, 4, 6 and $8 \mathrm{~h}$. Cells were further incubated up to $10 \mathrm{~h}$. At this time, supernatants were collected and clarified by centrifugation $\left(3,500 \times g\right.$ at $\left.4^{\circ} \mathrm{C}\right)$ and the virus production was determined by viral plaque assays.

\section{Statistical analysis}

Data are presented as means \pm standard deviation (SD). A one-way ANOVA with Bonferroni a posteriori test was used to compare differences between groups. A $p<0.05$ was considered significant. The $\mathrm{EC}_{50}$ and $\mathrm{CC}_{50}$ values were calculated using GraphPad Prism software v. 5.01.

\section{Additional files}

\section{Additional file 1: TLC profile of OE and AE of $B$. gaudichaudiana,}

B. spicata and T. absinthioides. Right Panels (A and B) showed the OE profiles in silica gel in (A-) ethylacetate:toluene:formic acid:methanol (2:2:1:1) revealed with NPR at $366 \mathrm{~nm}$; and (B-) toluene:ethylacetate (5:5) revealed with AniS, at visible light. Left panels ( $C$ and $D)$ correspond to AEs: (C-.) silica gel and ethylacetate:methanol:water (100:10:13) and SAni, at visible light; and (D-) AE profile in cellulose with ACH 15\% and NPR at 366 nm. BG (B. gaudichaudiana); BS (B. spicata) and TA (T. absibthioides).

\section{Additional file 2: HPLC profile of $F_{C}$ and $F_{D}$ from the OE of}

B. gaudichaudiana. A gradient of mobile phase system consisting of water $(A)$ and $\mathrm{MeOH}(B)$ used was: 0-15 min: $2 \rightarrow 98 \%$ A; 15-20 min: isocratic $98 \% \mathrm{~A} ; 20-21 \mathrm{~min}: 98 \rightarrow 2 \% \mathrm{~A}$.

Additional file 3: UV spectra of purified apigenin. A.- UV spectra with methanol $(\mathrm{MeOH})$ and $\mathrm{MeOH}$ with sodium methoxide (MeONa); B.- UV spectra with $\mathrm{MeOH}, \mathrm{MeOH}$ with aluminium chloride (AlCl3), $\mathrm{MeOH}+\mathrm{AlCl} 3+$ chloridric acid $(\mathrm{HCl})$ and $\mathrm{MeOH}+\mathrm{AlCl} 3+\mathrm{HCl} 5$ minutes later; $\mathrm{C}$.- UV spectra with $\mathrm{MeOH}, \mathrm{MeOH}+$ sodium acetate $(\mathrm{AcONa})$ and $\mathrm{MeOH}+\mathrm{AcONa}+$ boric acid ( $\mathrm{H3BO} 4)$

Additional file 4: IR spectra of purified apigenin.

Additional file 5: HPLC of standard apigenin (Sigma). The inserts show the UV adsorption spectra of the major peak detected. HPLC with a RP-18 column, using a water (A)-methanol (B) gradient: 0-2 50\% A; 2-15 $\min : 50 \rightarrow 98 \%$ A, 15-25 min: isocratic $98 \%$ A, 26-30 min: $98 \rightarrow 50 \%$ A flow rate $=1 \mathrm{ml} / \mathrm{min}$ monitored at $336 \mathrm{~nm}$.

\section{Competing interests}

The authors declare that they have no competing interests.

\section{Authors' contributions}

MFVJ designed and carried out the antiviral and cytotoxicity studies, the extract preparation, TLC profiles and drafted the manuscript. FR carried out the fractionation of $\mathrm{Bg} \mathrm{OE}$ and the HPLC analyses. LM and RHC participated in the design of the study. VM and LVC conceived the whole study and edited the manuscript. All authors read and approved the final manuscript.

\section{Acknowledgements}

This work was supported by grants B045; B037 from the Universidad de Buenos Aires (UBACYT 2008-2011); and grant PIP 112-200801-01169 from the Consejo Nacional de Investigaciones Científicas y Tecnológicas, Argentina. We acknowledge Martha Gattuso and Susana Gattuso from Universidad Nacional de Rosario, Gustavo Giberti from Universidad de Buenos Aires and Alberto Slanis from Instituto Miguel Lillo from Universidad Nacional de Tucumán for collection and identification of plant material. We also thank Pharm. Daiana Retta for providing B. gaudichaudiana plant material; Dr. Eliana F. Castro for encouraging discussions Ms. María Teresa Argerich (CONICET) for her technical assistance.

\section{Author details}

${ }^{1}$ Cátedra de Virología, Facultad de Farmacia y Bioquímica, Universidad de Buenos Aires, Junín 956, 4P, Ciudad de Buenos Aires, 1113, Argentina. ${ }^{2}$ Cátedra de Farmacognosia, Instituto de Química y Metabolismo del Fármaco (IQUIMEFA), Facultad de Farmacia y Bioquímica, Universidad de Buenos Aires, Junín 956, 2P, Ciudad de Buenos Aires, Argentina.

Received: 20 November 2012 Accepted: 24 July 2013

Published: 27 July 2013

\section{References}

1. De Clercq E, Field HJ: Antiviral prodrugs - the development of successful prodrug strategies for antiviral chemotherapy. Br J Pharmacol 2006, 147:1-11.

2. Kitazato $K$, Wang $Y$, Nobayashi $K$ : Viral infectious disease and natural products with antiviral activity. Drug Discov Ther 2007, 1:14-22.

3. Giberti G: Ethnobotanical data and herbarium information from Argentina: Tools for medicinal plant research. In South American Medicinal Plants as a Potential Source of Bioactive Compounds. 1st edition. Edited by Martino V, Muschietti LV. Kerala: Transworld Research Network; 2008:1-13.

4. Barboza GE, Cantero JJ, Núñez C, Pacciaroni A, Ariza Espinar LA: Medicinal plants: a general review and a phytochemical and ethnopharmacological screening of the native argentine flora. KURTZIANA 2009, 34:7-365.

5. Akaike $S$, Sumino M, Sekine T, Seo S, Kimura N, Ikegami F: A new entclerodane diterpene from the aerial parts of Baccharis gaudichaudiana. Chem Pharm Bull 2003, 51:197-199.

6. Zardini EM: Etnobotánica de Compuestas Argentinas con especial referencia a su uso farmacológico. Acta Farm Bon 1984, 3:77-99. and 169-194.

7. Martinez Crovetto R: Las plantas utilizadas en medicina popular en el Noroeste de Corrientes. República Argentina. Miscelánea Fundación Miguel Lillo 1981, 69:7-139.

8. Martinez Crovetto R: Estudios Etnobotánicos. I. Nombres de plantas y su utilidad según los indios Tobas del este de Chaco. Bonplandia 1964 1:279-333

9. de Souza GC, Haas AP, von Poser GL, Schapoval EE, Elisabetsky E: Ethnopharmacological studies of antimicrobial remedies in the south of Brazil. J Ethnopharmacol 2004, 90:135-143.

10. Toursarkissian M: Plantas medicinales de la Argentina: sus nombres botánicos, vulgares, usos y distribución geográfica. Buenos Aires: Eds: Hemisferio Sur; 1980:1-178.

11. Scrivanti LR, Zunino MP, Zygadlo JA: Tagetes minuta and Schinus areira essential oils as allelopathic agents. Biochem Syst Ecol 2003, 31:563-572.

12. Tereschuk ML, Riera MVQ, Castro GR, Abdala LR: Antimicrobial activity of flavonoids from leaves of Tagetes minuta. J Ethnopharmacol 1997, 56:227-232

13. García CC, Talarico L, Almeida N, Colombres S, Duschatzky C, Damonte EB: Virucidal activity of essential oils from aromatic plants of San Luis, Argentina. Phytother Res 2003, 17:1073-1075.

14. Antoine TE, Park PJ, Shukla D: Glycoprotein targeted therapeuthics: a new era of anti-herpes simplex virus-1 therapeutic. Rev Med Virol. in press.

15. Piret J, Boivin G: Resistance of herpes simplex viruses to nucleoside analogues: mechanisms, prevalence, and management. Antimicrob Agents Chemother 2011, 55:459-472.

16. World Health Organization: Poliomyelitis, Fact sheet no. 114. http://www.who. int/mediacentre/factsheets/fs114/en/

17. Couzin J: Report concludes polio drugs are needed-after disease is eradicated. Science 2006, 311:1539.

18. Buckwold VE, Beer BE, Donis RO: Bovine viral diarrhea virus as a surrogate model of hepatitis $C$ virus for the evaluation of antiviral agents. Antiviral Res 2003, 60:1-15.

19. Whelan SPJ: Vesicular Stomatitis Virus. In Encyclopedia of Virology. 3rd edition. Edited by Mahy BWJ, van Regenmortel MHV. Academic Press, Elsevier Ltd; 2008:291-299.

20. Mabry TJ, Markham KR, Thomas MB: The Systematic Identification of Flavonoids. Berlin: Springer Verlag; 1970:81.

21. Abad MJ, Bermejo P, Gonzales E, Iglesias I, Irurzun A, Carrasco L: Antiviral activity of Bolivian plant extracts. Gen Pharmacol 1999, 32:499-503. 
22. Abad MJ, Bermejo P, Sanchez Palomino S, Chiriboga $X$, Carrasco L: Antiviral activity of some South American medicinal plants. Phytother Res 1999, 13:142-146.

23. Sanchez Palomino S, Abad MJ, Bedoya LM, García J, Gonzales E, Chiriboga X, Bermejo P, Alcami J: Screening of South American plants against human immunodeficiency virus: preliminary fractionation of aqueous extract from Baccharis trinervis. Biol Pharm Bull 2002, 25:1147-1150.

24. García CC, Rosso ML, Bertoni MD, Maier MS, Damonte EB: Evaluation of the antiviral activity against Junin virus of macrocyclic trichothecenes produced by the ypocrealean epibiont of Baccharis coridifolia. Planta Med 2002, 68:209-212.

25. Torres CV, Domínguez MJ, Carbonari JL, Sabini MC, Sabini LI, Zanon SM: Study of antiviral and virucidal activities of aqueous extract of Baccharis articulata against Herpes suis virus. Nat Prod Commun 2011, 6:993-994.

26. Genovese D, Catone S, Farah ME, Gambacorta A, Fiore L: Isolation and biological characterization of $3(2 \mathrm{H})$-isoflavene-resistant and -dependent poliovirus type 2 Sabin mutants. J Gen Virol 1999, 80:157-167.

27. Verheyden B, Lauwers S, Rombaut B: Quantitative RT-PCR ELISA to determine the amount and ratio of positive- and negative strand vira RNA synthesis and the effect of guanidine in poliovirus infected cells. J Pharm Biomed Anal 2003, 33:303-308.

28. Fullas F, Hussain RA, Chai HB, Pezzuto JM, Soejarto DD, Kinghorn AD: Cytotoxic constituents of Baccharis gaudichaudiana. J Nat Prod 1994, 57:801-807

29. Sithisarna P, Michaelisa M, Schubert-Zsilaveczb M, Cinatl J Jr: Differential antiviral and anti-inflammatory mechanisms of the flavonoids biochanin a and baicalein in $\mathrm{h} 5 \mathrm{n} 1$ influenza a virus-infected cells. Antiviral Res 2013, 97:41-48.

30. Manvar D, Mishra M, Kumar S, Pandey VN: Identification and evaluation of anti hepatitis $C$ virus phytochemicals from Eclipta alba. J Ethnopharmacol 2012, 144:545-554.

31. Chiang LC, Ng LT, Cheng PW, Chiang W, Lin CC: Antiviral activities of extracts and selected pure constituents of Ocimum basilicum. Clin Exp Pharmacol Physiol 2005, 32:811-816.

32. Critchfield JW, Butera ST, Folks TM: Inhibition of HIV activation in latently infected cells by flavonoid compounds. AIDS Res Hum Retroviruses 1996, 12:39-46.

33. Finkielsztein LM, Castro EF, Fabián LE, Moltrasio GY, Campos RH, Cavallaro LV, Moglioni AG: New 1-indanone thiosemicarbazone derivatives active against BVDV. Eur J Med Chem 2008, 43:1767-1773.

doi:10.1186/1743-422X-10-245

Cite this article as: Visintini Jaime et al: In vitro antiviral activity of plant extracts from Asteraceae medicinal plants. Virology Journal 2013 10:245.

\section{Submit your next manuscript to BioMed Central and take full advantage of:}

- Convenient online submission

- Thorough peer review

- No space constraints or color figure charges

- Immediate publication on acceptance

- Inclusion in PubMed, CAS, Scopus and Google Scholar

- Research which is freely available for redistribution 